JOURNAL OF SECURITY AND SUSTAINABILITY ISSUES

ISSN 2029-7017 print/ISSN 2029-7025 online

2018 December Volume 8 Number 2

https://doi.org/10.9770/jssi.2018.8.2(5)

\title{
Scopus
}

\section{RISK MANAGEMENT IN THE SUSTAINABLE DEVELOPMENT: ANALYSIS OF A SELECTED KEY INDUSTRY}

\author{
Josef Abrhám ${ }^{1}$, Petr Lžičař ${ }^{2}$ \\ ${ }^{1}$ Metropolitan University Prague, Dubečská 900/10, 10031 Prague, Czech Republic \\ ${ }^{2}$ Le Hotels Group, Truhlářská 16, 11000 Prague, Czech Republic \\ E-mails: e-mail: 'josef.abrham@mup.cz ; ${ }^{2}$ petr.lzicar@le-hotels.cz
}

Received 15 March 2018; accepted 10 November 2018; published 30 December 2018

\begin{abstract}
Our paper focuses on the analysis of the the role of risk management in sustainable hotel chain policy. We tackle the issue of risk evaluation and prevention in hotel industry as a factor of enhancing its entrepreneurial value. Our empirical value-added is based on its own novel survey based on a case study of a chosen company. We evaluate the problem areas of risk management and make suggestions for the hotel optimization procedures based on our results and findings. Furthremore, we compare the outcomes of our research with those of the the studies conducted by the renown foreign companies and focusing on payment discipline and risk management. Our results demonstrate that in order to optimize the cash flow in hotel operations, it is advisable to provide a balanced business mix and improvement of strategic internal processes. Moreover, it appears that for the optimal application of the risk management it is important that a new or updated strategic analysis is conducted annually within the business entity according to the development of both the external and internal environment. Furthremore, financial and payment risks need to be integrated into the formulation of strategic goals so as to identify which of them can put the strategy and its strategic goals at stake.
\end{abstract}

Keywords: risk management; sustainability; tourism; payment discipline; hospitality

Reference to this paper should be made as follows: Abrhám, J.; Lžicar, P. 2018. Risk management in the sustainable development: analysis of a selected key industry Journal of Security and Sustainability Issues 8(2): 171-180. https://doi.org/10.9770/jssi.2018.8.2(5)

JEL Classifications: L25; L83; G22

\section{Introduction}

Contemporary societies encounter wide range of threats, therefore recognizing, preventing and management of those threats have become one major preconditions of sustainable development process (Korauš et al., 2016; Fabuš, M. 2017; Korauš et al., 2017a; 2017b; Mishenin, et al. 2018; Tvaronavičienė, 2018; Veselovská et al., 2018). The presented research will tackle a case of one of key industries, specifically a hotel industry. In the hotel industry, an important role in successful sustainable entrepreneurship is played by a payment discipline of business partners and business mix. Poor payment morale can significantly affect the cash flow and, therefore, the payment capabilities of a hotel (see Abrhám and Wang, 2017). For this reason, it is desirable to include payment discipline not only in the financial management but also in the risk management (Abadi et al., 2018). These are one of the most notorious problems companies in the Central and Eastern European countries (CEEC) are often facing with an adverse effect on their performance and profitability (see Abrhám et al., 2015a; Abrhám et al., 2015b; Jiroudková et al., 2015; Ehrenberger et al., 2015; Vasylchak and Halachenko, 2016; Jelínková et al., 2017; Filipishyna et al., 2018; Mackevičius et al., 2018; Narkunienė, Ulbinaite, 2018; Zemguliene Valukonis, 2018; Volchik et al. 2018). 
The aim of this article is to analyse the role of risk management in hotel chain policy through its own empirical survey within the case study of a chosen company. On the basis of the findings gathered, the problem areas of the risk management are evaluated, and hotel optimization procedures are proposed.The results of our own research are compared with the studies by renowned foreign companies focused on payment discipline and risk management.

The theoretical groundwork of the study constitutes a clarification of the attitudes to risks and the risk management in the hotel sector as well as the observation of the payment discipline. The empirical survey focused on the payment discipline in relation to individual countries was implemented in cooperation with travel agencies, lasted one year and took place between September 2015 and September 2016. That part of the research was implemented in cooperation with travel agencies. The summary data on payment morale of the business partners of Le Hotels Group s.r.o. that were evaluated dated to the period 2016 to 2017 . The information on the number of overdue invoices related to both the maturity and the country of origin of the business partners (travel agencies) was evaluated through a relative frequency, which also applies to the evaluation of the total data on the payment discipline.

\section{Risk management in analysed industry: theoretical grounds}

Main risks in the hotel sector include, among other things, seasonality, unreliability of business partners, fluctuations or low motivation of employees or highly competitive environment (Ambrosetti et al., 2014; Čábelková et al. 2015; Niño-Amézquita et al., 2017; Dung et al., 2018). Risk management in the hotel industry is part of strategic management, which focuses specifically on prevention and reduction or elimination of the risks through specific methods and procedures. Risk management practices in the hotel industry depend on a variety of factors, including the size of the hotel and the fact whether the hotel is part of a hotel network or operated independently (see Waikar et al., 2016).

Risk management is one of the important components of the strategic management as a set of management decisions that determine the long-term performance not only of the hotel but also of any other business company (see Grasserová et al., 2012; Strielkowski et al., 2014). Each strategic plan is based on a set of assumptions that do not have to be met in the current period of globalization of the economy and the turbulence of the business environment, and indeed, the assumptions are, to certain extent, not fulfilled (see Fotr et al., 2012). The management of the hotel shall therefore be able to flexibly respond to changed conditions, which is the task of risk management and, in some cases, of the crisis management aimed, among other things, at mitigating the impacts of natural disasters. In those cases, the cooperation of hotel management with local public administration plays a key role as proved in case of the devastation of the Japanese tourist destination Tohoko affected in 2011 by the tsunami (Nguyen et al., 2017). The risk management should significantly reduce the negative impacts of unfavourable business environment developments on the results of the strategic plans of the hotel; one of the negative impacts on the chosen strategy may be the negative consequences for cash flow as a result of poor payment discipline of the business partners. The consequences of bad payment morale trigger further changes in processes and resources of hotel companies, have a longer life cycle, and thus have a retrospective effect on the strategic management (Russel-Jones, 2016).

Responsibility for risk management is spread across organizations throughout the management. The highest responsibility is naturally on the owner, the statutory body and the top management of the company (Rais, 2010; Radovic et al., 2017). In small hotels (see the division of companies by size in the subchapter payment discipline), the responsibility for risk management is concentrated at the level of the statutory body because it is not efficient to employ a specialized full-time risk manager. In medium and large hotel companies, responsibility is spread over individual managers. Large hotel companies (hotel chains) have a designated specialist (risk manager). Almost in all cases, the risk management is associated with the role of the CFO, as the impact of risks (damages) as well as the countermeasures can be expressed financially and have an impact on financial planning. This impact in the hotel industry can be also described as operational risks or operational changes. Financial performance of an enterprise influences the risk management and vice versa. 
As an example, we can put the role of the risk management in the rising debt of the hotel; in this situation its financial position and the risk of creditors are deteriorating, which significantly influences the interest rate of foreign capital (Fíbriová and Šoljáková, 2005). Risk management consists of four interdependent phases: risk identification, risk assessment, risk management (or mitigation) and risk monitoring (Smejkal and Rais, 2009; Chiabai et al., 2014).

One area where the violation of ethical standards in the form of contract failures can have very fatal consequences on the cash flow (or even solvency) of a hotel company is a payment morale. The additive effect of very poor payment morale of the key business partners in a short period of time may represent a critical risk (see Table 1) and lead to crisis of the hotel. This applies in particular to small and medium-sized businesses. The crisis of an enterprise usually occurs after the break of the balance between the enterprise and its surroundings takes place (Zuzak, 2008), which is precisely the case of poor payment morale of business partners of the enterprise.

Table 1. Share of late settlement from partners (in \%)

\begin{tabular}{|c|c|c|c|c|c|c|c|c|}
\hline \multirow{2}{*}{ Country } & \multicolumn{3}{|c|}{ More than 60 days } & \multicolumn{3}{c|}{ More than 90 days } & \multicolumn{2}{c|}{ More than 120 days } \\
\cline { 2 - 10 } & Le Hotels & Bisnode & Atradius & Le Hotels & Bisnode & Atradius & Le Hotels & Bisnode \\
\hline Greece & 28,0 & 4,9 & 16,9 & 22,0 & 3,6 & 6,5 & 5,0 & 4,1 \\
\hline Portugal & 9,0 & 3,5 & - & 12,0 & 3,0 & - & 19,0 & 6,6 \\
\hline Italy & 9,0 & 4,2 & 15,6 & 9,0 & 2,9 & 4,1 & 5,0 & 2,2 \\
\hline Turkey & 6,0 & 1,9 & 10,5 & 12,0 & 1,5 & 6,2 & - & 4,3 \\
\hline Poland & - & 3,3 & 4,0 & 6,0 & 3,0 & 1,6 & 18,0 & 12,0 \\
\hline Great Britain & 8,0 & 2,6 & 2,1 & - & 1,3 & 0,8 & - & 1,3 \\
\hline Czech Republic & - & 1,1 & 1,4 & - & 0,4 & 1,8 & - & 0,3 \\
\hline
\end{tabular}

Source: Atradius (2016), Bisnode (2017), own research.

Payment discipline means the timeliness of the payment of the liability by the customer. The source of the risk is therefore the insufficient cash of the hotel caused by the late payment of the partner company. The payment morale is low if the business entity holds payments and pays its liabilities only after a set deadline. From the risk management point of view, the payment discipline is a fiscal risk (Merna, Faisal, 2007). In terms of financial management, payment discipline can be measured indirectly via debt turnover ratio. That indicator shows the average maturity of receivables, i.e. the number of days until the invoice is paid (Fotr et al., 2012). This indicator helps financial managers to determine how many days will elapse during which the collection of money is retained in receivables. During this time, the hotel has to wait for the collection of payments for its already made revenues for provided products and services (Kislingerová, 2007).

\section{Payment discipline in the international environment}

Payment morale is monitored by a number of reputable international companies. The research focuses on finding out data on payment discipline in individual countries, or according to the criteria of the size or business area of the business entity. Based on that data, companies can set appropriate risk management measures. The following are the results of the international studies by Bisnode (2017) and Atradius (2016).

From the results of the Bisnode (2017) study it can be summarized that the European average of paid receivables for the provided goods or services was improving on the maturity date. In $2014,37.6 \%$ of the invoices were paid at the time of maturity, while two years later that figure grew up to $39.1 \%$. This means that, out of the total number of receivables monitored in 2016, on the maturity date was paid on average $39.1 \%$ of receivables in the monitored countries. The mean value that divides the set into two equal halves had a value of $43.6 \%$ in 2016 . In 2014 and 2016 Denmark recorded the highest proportion of paid claims at the maturity time. Very good payment morale also showed Germany in the both years. By contrast, the northern countries such as Ireland and England, and the countries of Southern Europe like Romania and Portugal, rank among the countries with 
a low maturity on the due date. If we look at bad payment morale represented by the proportion of outstanding commitments for more than 90 days after the due date, we find that the United Kingdom and Ireland improved their rating, while the Southern European countries (Romania, Greece and Portugal) also here showed poor payment morale. Besides these countries we can name Turkey and Poland among the countries with a relatively high proportion of outstanding claims with 120 days past maturity (Bisnode, 2017).

In the case of the Czech Republic, it was found that both in 2014 and in 2016 there was a better proportion of matured receivables on the due date compared to the average of the countries surveyed. By maturity, $38.2 \%$ of the invoices were repaid in 2014, while two years later, the proportion of paid invoices grew by $6.5 \%$ up to $44.7 \%$. Within thirty days after the due date, $53.5 \%$ of invoices were paid in the Czech Republic in 2014, while in 2016 the proportion of invoices paid 30 days after the maturity fell to $49.3 \%$. In 2014, the companies paid $5.7 \%$ of invoices within sixty days after the due date. In 2016, the proportion of invoices paid in this period dropped to $4.2 \%$ of the total number of receivables tracked. The share of invoices outstanding three months after their maturity in 2014 amounted to $1.4 \%$ and then declined to $1.1 \%$ in 2016 (Bisnode, 2017).

Atradius divides its regular annual reports on payment discipline according to the defined world regions while for Europe the report in 2016 distinguishes between Western Europe and Eastern Europe. Western Europe includes Germany, Austria, Denmark, Great Britain, the Netherlands, Sweden, Switzerland, Ireland, Belgium, France, Greece, Spain and Italy. Eastern Europe is represented by the Czech Republic, Hungary, Poland, Slovakia and Turkey. The Atradius survey focuses on the payment discipline of the B2B (business to business) which means on the business relationships between two business partners. B2B relationships generally operate on the principle of the electronic data exchange. The Atradius International Survey focuses on a number of B2B areas (for example, the access to business credits for B2B business transactions), however from the perspective of this paper, the most important data is on the payment discipline. The data presented is divided into two main areas: 1) the average payment term - the average payment term recorded in Western Europe and Eastern Europe; and 2) the late payment - the percentage of respondents reporting late payment by B2B customers (Atradius, 2016).

From the Atradius research results, it can be seen that the difference in payment discipline between the countries of Western and Eastern Europe is not very striking, except when the invoice is paid after more than 90 days. In that period, across sectors, there is a better payment level shown for Western European countries. In the proportion of paid invoices within 30 days and within 60 days, Western and Eastern European companies doing business in the service sector are not much different. After that, however, there is a certain difference; more than 60 days after the maturity were paid $5.3 \%$ invoices in Western Europe while in Eastern Europe it was $6.8 \%$ of invoices (Atradius, 2016). The most significant differentiation in the payment discipline of Western European and Eastern European business entities in the service sector was reported in the payment of the invoice for more than 90 days. While in Western Europe less than $1 \%$ of the invoices were paid after 90 days, the proportion of those invoices in Eastern Europe was $4.5 \%$. In Western Europe, the companies in the service business got their invoice settled on average 29 days since they were issued while in Eastern Europe those companies received the payment on average after 30 days (Atradius, 2016). The analysis also focused on a payment morale indicator according to the size of the company. In the European Union, companies are sized as micro-enterprises (less than 10 employees), small businesses (10 to 49 employees), medium-sized enterprises (less than 250 employees) and large enterprises (Buculescu, 2013). Atradius, for the purpose of analysing the payment discipline, defined the categories of "micro-enterprises", "small and medium-sized enterprises" (SMEs) and "large enterprises". Hotels as separate units belong to the SME while the hotel chains belong to the category of large enterprises.

The Atradius study also shows that in the both monitored transnational regions, the micro-enterprises have the best payment morale, accounting for approximately $83 \%$ of invoices within 30 days, while approximately $72 \%$ applies for SMEs and $68 \%$ for large enterprises. The difference between the payment morale of Western European and Eastern European businesses, depending on the size of the firm, is reported in the invoices paid for 90 days or more from their issuance in all size categories of the businesses (Atradius, 2016). 
Looking more closely at the category of SMEs, which includes most hotels operated in the Czech Republic, the invoices paid more than 90 days account $1 \%$ in Western Europe, while in case of Eastern Europe based businesses the share of those invoices made $5.4 \%$ (Atradius, 2016). The Atradius survey results are partly in line with the results of the Bisnode survey presented above. Measured by the indicator of invoice repayment of more than 90 days, Greece and Spain belong among the worst countries (Portugal is missing in the analysis) and also France had poor payment morale. On the contrary, in Austria or Germany, the unpaid invoice after 90 days was not recorded at all. In Eastern Europe, by far the worst payment morale (measured by the number of outstanding invoices within 90 days) was in Turkey, where the proportion of due invoices within 90 days exceeded $6 \%$ which was similar to Greece and Spain mentioned above. Compared to other V4 countries the Czech Republic had the highest share of invoices repaid in more than 90 days, but when measured by the average day of the invoice reimbursement (26 days) it belonged among the leaders of the Central European countries. The average pay out of 26 days ranks the Czech Republic among the best countries also within Western Europe (Atradius, 2016).

In the above text there were presented the results of the Atradius study from the point of view of payment morale measured on the days after the issuance of the invoice. Another form of the measurement is a payment after the date that had been marked as the due date on the invoice. This is the proportion of companies in the total number of the examined companies that in their business activity encountered with a failure of their business partner to pay his invoice by the due date. The survey methodology differed slightly for the countries of Western and Eastern Europe. While data for Western Europe was broken down by both the sector and size of the companies without any distinction, whether the payment was received from a domestic or foreign company, the data in the Eastern European countries also reflected the company origin. According to the study, in Western Europe, more than $90 \%$ of the companies participating in the cross-industry study reported late payment; in the service sector it was approximately $92 \%$. In Eastern Europe there is a difference depending on whether the deal was made with a domestic or a foreign business partner. In the service sector the difference was almost 8 $\%$; in terms of a domestic business transaction, the companies recorded more than $90 \%$ of their late payment, while the share of late payments was less than $83 \%$ when trading with foreign partners.

The analysis of the overdue payment data according to the enterprise size shows that in Western Europe, the largest proportion of the invoices not paid by the due date emerged in the SME enterprises; over $95 \%$ of the businesses met with that late payment. As in the case of the overdue payment analysis according to the sectors, the difference in the late payments reported in Eastern Europe depended on whether the transaction was made with a domestic or a foreign partner. In all three size categories, the businesses had, in term of payment discipline, a better experience with foreign business partners than with domestic ones. In the SME category, approximately $87 \%$ of businesses encountered overdue payment in the domestic payments, while less than $4 \%$ of the firms have that negative experience in dealing with foreign companies.

\section{A case study}

As a data base for the analyses carried out within the case study, the Le-Hotels s.r.o. financial statements on the fulfilment of the specified financial and factual indicators were used. The information on the number of due or outstanding invoices according to the maturity and the country of origin of the business partners (travel agencies), were evaluated by means of a relative frequency, which is also true for the evaluation of the aggregated data on the payment discipline.

Since 2015, Le Hotels Group s.r.o. operates a total of five hotels in the capital of the Czech Republic Prague, with a total capacity of 1150 rooms (about 352 employees); specifically these are Grandior Hotel Prague, Grand Majestic Plaza, Grandium Prague, Élite and Hotel Majestic Plaza. The revenues department of the Le Hotels Group s.r.o., which is in charge of the sale of hotel rooms, had the lead in this study. The subjects of the analysis were both the company as a whole and the Grandior Hotel Prague alone. Its capacity of 393 rooms, due to its size, is sufficient to maintain a diversified business mix; thanks to its location and the conference facilities, it can attract both leisure and corporate clients and thus allows further analysis. 
From the analysis of the statistical data of Le-Hotels s.r.o company, we can see that business partners from the Czech Republic showed better payment morale than foreign companies. While within 30 days after the date of the issuance of the invoice, the hotel company received $70 \%$ (or $80 \%$ ) of the payments from its domestic business partners out of the total domestic payments, from the foreign ones it was by $11 \%(10 \%)$ less. In terms of unpaid invoices after 60 days, there was a relatively high difference between the domestic and foreign business partners (travel agencies) in 2016, but in 2017 that ratio was equivalent. These findings do not correspond to the results of the Atradius research study presented above, which, in case of Eastern European businesses (measured by the share of respondents with experience of late payment) found the worse payment morale in case of domestic payment system compared to the payment from abroad. The average day of the invoice payment from both domestic and foreign partners in 2016 was the 29th day after the invoice was issued; in 2017 the average was reduced by two days on the 27th day. Overall, the business partners of Le-Hotels s.r.o had slightly better payment morale in 2017 compared to 2016. From a comparison of the payment discipline of Le-Hotels s.r.o business partners (travel agencies) by country, it is clear that the total debt of travel agencies based in Europe amounted to $4 \%$ and the total percentage debt of hotel accommodation customers made $4.51 \%$ on the due date.

The payment discipline of the partners from each country was monitored individually according to the due period from the maturity date. The highest percentage of outstanding invoices within 30 days of maturity was reported by travel agents from England and Finland (8\%). French and Portuguese travel agents did not pay their liabilities after 30 days of maturity in $7 \%$ of the cases, while Italian, Belgian, Spanish, Slovak and Czech did not pay for in $6 \%$ of the cases. The largest proportion of debtors within 60 days of maturity recruited from the Greek travel agencies (13\%). The second largest number of the outstanding invoices for accommodation services within 60 days was reported for Turkish travel agents (11\%). A relatively high number also appeared in case domestic and English service providers (7\%). On the contrary, in case of the Nordic countries (Finland, Denmark), there is a good payment culture. The share of Greek travel agencies in the total number of the outstanding invoices within 90 days of maturity increased to $28 \%$. It can be seen from the data that Southern states have probably worse payment morale than Northern countries; Portuguese travel agencies reported $9 \%$, Turkish $6 \%$ and Spanish $4 \%$ share of the total number of the outstanding invoices. In the Northern countries, the surveyed company made the worst experience with English travel agencies, which showed an $8 \%$ share of the total number of outstanding claims within 90 days after the due date. From the data analysed, it can be observed that the established trend continued also in case of 120 days within the maturity of the accommodation invoice. The largest share out of total outstanding commitments in the given period was reported again for Greek (22\%), Portuguese (12\%) and Turkish (12\%) travel agents from Southern Europe. Furthermore, in terms of 120 days after the due date, the largest debtors are Greek travel agencies. Their share makes $28 \%$ out of the total number of unpaid claims for more than four months. Portuguese travel agencies followed with $19 \%$. In contrast to shorter time periods, the proportion of Polish travel agents (18\%) increased.

Looking at the overall data (Table 2), i.e. the share of all outstanding invoices for accommodation after maturity, we will get somewhat surprising data. The Danish (12\%), German (10\%) and Turkish (7\%) travel agencies reported the highest proportion of the outstanding invoices within 30 days, while a very low proportion of unpaid invoices within 30 days were reported for Portuguese (2\%), English (3\%) and Irish (3\%) travel agencies. The proportion of the unpaid invoices by Czech travel agencies made 5\%. The feature of surprise of this finding stems out of the comparison with other research data. According to the Bisnode survey (for 2016), Danish and German companies showed a very high proportion of the invoices repaid at their maturity (Danish companies recorded even the highest share which was $90.3 \%$ of the repaid invoices at maturity), while the Irish, English and Czech recorded relatively low share of paid invoices by maturity (30 days). Turkey stood at the centre of that imaginary peloton. Also, the Atradius survey shows that Denmark and Germany are among the countries with the best payment discipline in Europe, measured by invoice parameters paid within 30 days. It is thus surprising that the findings of Bisnode and Atradius differ greatly in terms of England, Ireland, the Czech Republic and other countries. 
Table 2. Share of settled invoices according to payment periods (in \%)

\begin{tabular}{|l|c|c|c|c|c|}
\hline \multirow{2}{*}{ Settlement date } & \multirow{2}{*}{ Le Hotels } & \multicolumn{2}{c|}{ Atradius Southern Europe } & \multicolumn{2}{c|}{ Atradius Western Europe } \\
\cline { 3 - 6 } & & Service sector & SMEs & Service sector & SMEs \\
\hline 0 - 30 days & 64,5 & 77,4 & 70,2 & 80,0 & 72,3 \\
\hline 31 - 60 days & 26,2 & 15,8 & 20,1 & 14,5 & 18,4 \\
\hline 61 - 90 days & 4,7 & 2,3 & 4,5 & 4,7 & 8,4 \\
\hline More than 90 days & 4,6 & 4,5 & 5,2 & 0,8 & 1,0 \\
\hline Average settlement period in 2016 & 29 & 28 & 34 & 29 & 33 \\
\hline
\end{tabular}

Source: Atradius (2016), Bisnode (2017), own research

A completely different picture of the country-specific payment discipline of travel agencies with which LeHotels concluded contracts shows the share of the paid invoices within a period of 30 days after the due date, in other words between 30 days and 60 days after the date the invoice was issued. With some exaggeration, it can be deduced that the Danish and German travel agencies pay the invoice 31 days after the invoice was issued, the first day after the due date. The share of the unpaid invoices from the German and Danish travel agencies out of the total outstanding amounts in the period of 30-60 days after the invoice was issued made $3 \%$ in case of German travel agents and $1 \%$ of Danish travel agents. The highest share of unpaid invoices in this period was reported by English, Finnish (both $8 \%$ share of outstanding invoices), French and Portuguese travel agents (7\%). The Czech travel agencies showed a $6 \%$ share of outstanding invoices within 60 days.

The results show that the most-risky countries across all timeframes are Greece and Portugal, which are among the countries with the worst payment morale in all three research surveys. Looking closer to the deadlines, Czech travel agencies must probably count on the fact that many companies in Turkey and Italy pay more than 60 days but less than 90 days, as shown by the Atradius survey. The research survey showed that the worst payment morale, measured by the „border-line“, non-reimbursement parameter for the services provided within 90 days, is reported for travel agents from Greece, Portugal, Turkey and Italy. The total number of the outstanding invoices within 90 days of the due date was the share of Greek travel agencies with $28 \%$ (respectively $22 \%$ which means that $22 \%$ of the outstanding invoices in the period of more than 90 were not received by Le-Hotels s.r.o. from the Greek travel agents), Portuguese travel agencies with $9 \%$ (12\%), Italian travel agencies with $9 \%(9 \%)$ and Turkish travel agencies with $6 \%(12 \%)$. The very poor payment morale of some Polish travel agencies, measured by the invoice default parameter of more than 120 days after maturity, confirms the Bisnode survey.

At this point, we compare Le Hotels' payment data with the results of the Atradius survey in relation to the sector and the size of the business. Le Hotels s.r.o operates in the service sector and ranks among SMEs. The investigation revealed that Le Hotels s.r.o. belongs among $91 \%$ of companies in Eastern Europe doing business in the service sector that experienced a late payment from a domestic business partner, respectively among $87 \%$ of companies that experienced a late payment from an indigenous partner. In terms of the size, Le Hotels s.r.o ranks among $87 \%$ of Eastern European SMEs that encountered with payment for their services after 99 days after the maturity when dealing with a foreign company or among $83 \%$ of SMEs, which received a late payment from a domestic business partner. Having compared the average data of the payment discipline of both the domestic and foreign partners of the Le-Hotels s.r.o. (travel agents) with the results of the Atradius study (B2B) it appears that the payment discipline of these partners to a large extent corresponded to the payment culture (in the service sector and B2B among B2B) in Eastern Europe and was worse than the payment morale of Western European companies. 


\section{Conclusions and implications}

Based on the empirical survey of business partners' payment discipline in the case study (of the chosen company Le Hotels s.r.o.), it can be concluded that the worst payment morale of the business partners is reported for travel agencies based in Greece and Portugal, as also confirmed by other research surveys. On the basis of the monitoring of the fulfilment of the financial indicators for the payment discipline, the Czech companies active (not only) in the hotel industry should keep certain vigilance when trading with Italian, Turkish and Polish companies. In order to optimize the cash flow in hotel operations, it is advisable to provide a balanced business mix, establish a local company (intermediary), and improve strategic internal processes.

Receiving payments on time is one of the most difficult and risky components of the hotel business. From the of view of the risk management in the field of payment discipline, it is now strategically negative for the Czech companies engaged in the hotel industry to enter into business contracts with Greek, Portuguese, Italian, Turkish and Polish partners without the need for "hotel prepayments" for "provided services". These "prepayments" must be settled between the hotel company and its business partner, at least one to two months before the accommodation is made so as to prevent the hotel company from becoming insolvent.To reduce the risk due to poor payment morale, it is recommended to introduce the obligation for these travel agencies to pay via virtual credit cards, when the hotel receives only the credit card number and the financial limit. The hotel company will ask in case of bad-paying business partners to withdraw the money for accommodation or conference events because they cannot get them physically at a given time. A measure in the form of establishing a local company is ideal when it comes to a group business, a group of tourists. It is mostly around 25 rooms and more. For safe "cash flow" at this moment we have to apply so called pre-payment taking place least one month before such a deal, that is, before the arrival of a tourist group. With this step, we can ensure a financial guarantee that the group will really come and the hotel will not be left empty and at the same time it has the funds before the event is held. Within the internal control process, regular monthly "credit meetings" can be recommended. These analyses focused on partners' payment discipline are attended by representatives of the financial and commercial departments. Based on the output data from both departments, it is possible to assess the cash flow of hotel companies and to organize relationships with individual business partners. For the optimal application of the risk management it is important that a new or updated strategic analysis is conducted annually within the business entity according to the development of both the external and internal environment. Financial and payment risks need to be integrated into the formulation of strategic goals so as to identify which of them can put the strategy and its strategic goals at stake.

\section{References}

Abadi, F.; Sahebi, I.; Arab, A.; Alavi, A.; Karachi, H. 2018. Application of best-worst method in evaluation of medical tourism development strategy. Decision Science Letters 7(1):77-86. https://doi.org/10.5267/j.ds1.2017.4.002

Abrhám, J.; Bilan, Y.; Krauchenia, A.; Strielkowski, W. 2015a. Planning horizon in labour supply of Belarusian small entrepreneurs. Economic research-Ekonomska istraživanja 28(1):773-787. https://doi.org/10.1080/1331677X.2015.1084238

Abrhám, J.; Strielkowski, W.; Vošta, M.; Šlajs, J. 2015b. Factors that influence the competitiveness of Czech rural small and medium enterprises. Agricultural Economics-Zemedelska Ekonomika 61(10):450-460. https://doi.org/10.17221/63/2015-AGRICECON

Abrhám, J.; Wang, J. 2017. Novel trends on using ICTS in the modern tourism industry. Czech Journal of Social Sciences, Business and Economics 6(1):37-43. https://doi.org/10.24984/cjssbe.2017.6.1.5

Ambrosetti, E.; Cela, E.; Strielkowski, W.; Abrhám, J. 2014. Ukrainian Migrants in the European Union: a Comparative Study of the Czech Republic and Italy. Sociologija i Prostor 52(2):141-166.

Atradius. 2016. Payment Practices Barometer Eastern Europe. Barcelona: Grupo Catalana Occidente. Available on the Internet: https:// group.atradius.com/publications/payment-practices-barometer-easern-europe-2017.html

Bisnode. 2017. Platební morálka firem je v Česku lepší než v Evropě [Paying morale in Czekia is worse than in Europe]. Praha: Bisnode Czech Republic.

Buculescu, M.M. 2013. Harmonization process in defining small and medium-sized enterprises. Arguments for a quantitative definition 
versus a qualitative one. Theoretical and Applied Economics 9(586):103-114.

Čábelková, I.; Abrhám, J.; Strielkowski, W. 2015. Factors influencing job satisfaction in post-transition economies: the case of the Czech Republic. International Journal of Occupational Safety and Ergonomics 21(4):448-456. https://doi.org/10.1080/10803548.2015.1073007

Chiabai, A.; Platt, S.; Strielkowski, W. 2014. Eliciting users' preferences for cultural heritage and tourism-related e-services: a tale of three European cities. Tourism Economics 20(2):263-277. https://doi.org/10.5367/te.2013.0290

Dung, H. C.; Thanh, P. T. K.; Oanh, D. V.; Long, N. H. 2018. Local Government Involvement in Small Tourism Firms Investment: The Case of Phu Tho Province, Vietnam. Economics and Sociology 11(2):97-111. https://doi.org/10.14254/2071-789X.2018/11-2/7

Ehrenberger, M.; Koudelkova, P.; Strielkowski, W. 2015. Factors influencing innovation in small and medium enterprises in the Czech Republic. Periodica Polytechnica Social and Management Sciences 23(2):73-83. https://doi.org/10.3311/PPso.7737

Fabuš, M. 2017. Current development of business environment in Slovakia and Czech Republic, Entrepreneurship and Sustainability Issues 5(1): 127-137. https://doi.org/10.9770/jesi.2017.5.1(10)

Fibírová, J., Šoljaková, L. 2005. Hodnotové nástroje řízení a měrení výkonnosti podniku [Value instrumenst and company management and performance measuring tools]. Praha: APSI.

Filipishyna L, Bessonova S, Venckeviciute, G. 2018. Integral assessment of developmental stability: cases of Lithuania and Ukraine. Entrepreneurship and Sustainability Issues 6(1): 87-99. https://doi.org/10.9770/jesi.2018.6.1(7)

Fotr, J.; Vacík, E.; Souček, I. 2012. Tvorba strategie a strategické plánováni [Making the strategy and strategic planning]. Praha: Grada Publishing.

Grasseová, M.; Dubec, R.; Řehák, D. 2012. Analýza podniku v rukou manažera. 33 nejpouživanějšich metod strategického řízení [Firm analysis in the hands of a manager: 33 widely-used methods of stratgegic planning]. Brno: BizBooks.

Jelínková, D.; Tučková, Z.; Jurigová, Z. 2017. Market segment of families with children: a new stimulus for modern Czech spa industry? Journal of International Studies 10(2):158-169. https://doi.org/10.14254/2071-8330.2017/10-2/12

Jiroudková, A.; Rovná, L. A.; Strielkowski, W.; Šlosarčík, I. 2015. EU Accession, Transition and Further Integration for the Countries of Central and Eastern Europe. Economics and Sociology 8(2):11-25. https://doi.org/10.14254/2071-789X.2015/8-2/1

Kislingerová. E. 2007. Manažerské finance [Managerial Finance]. Praha: C.H.BECK.

Kocabiykoglu, A.; Gogus, C. 2015. Revenue Management vs. Newsvendor Decisions: Does Behavioral Response Mirror Normative Equivalence? Production and Operations Management 24(5):750-761. https://doi.org/10.1111/poms.12297

Korauš, A., Dobrovič, J., Ključnikov, A., Gombár, M. 2016. Customer Approach to Bank Payment Card Security and Fraud, Journal of Security and Sustainability Issues 6(1): 85-102. http://dx.doi.org/10.9770/jssi.2016.6.1(6)

Korauš, A., Dobrovič, J., Rajnoha, R., Brezina, I. 2017a. The safety risks related to bank cards and cyber attacks, Journal of Security and Sustainability Issues, 6(4): 563-574. http://doi.org/10.9770/jssi.2017.6.4(3)

Korauš, A.; Veselovská, S.; Kelemen P .: 2017b. Cyber security as part of the business environment in Zborník z konferencie Medzinárodné vzt'ahy 2017: Aktuálne otázky svetovej ekonomiky a politiky, Smolenice 30. novembra - 1. Decembra 2017, Vydavatel'stvo Ekonóm, 1113 s., ISBN 978-80-225-4488-7, ISSN 2585-9412

Kumara, R.; Ramachandranb, P. 2016. Revenue management in remanufacturing: perspectives, review of current literature and research directions. International Journal of Production Research 54(7):2185-2200. https://doi.org/10.1080/00207543.2016.1141255

Mackevičius J, Šneidere R, Tamulevičienė, D. 2018. The waves of enterprises bankruptcy and the factors that determine them: the case of Latvia and Lithuania. Entrepreneurship and Sustainability Issues 6(1): 100-114. https://doi.org/10.9770/jesi.2018.6.1(8)

Mccafrey, D.; Walczak, D. 2016. Optimal Dynamic Upgrading in Revenue Management. Production \& Operations Management 25(11):1855-1865. https://doi.org/10.1111/poms.12581

Merna, T.; Thani-al, F. 2008. Corporate Risk Managament. $2^{\text {nd }}$ edn., Hoboken, New Jersey: Wiley.

Mishenin Y, Koblianska I, Medvid V, Maistrenko, Y. 2018. Sustainable regional development policy formation: role of industrial ecology and logistics. Enterpreneurship and Sustainability Issues 6(1): 329-341. https://doi.org/10.9770/jesi.2018.6.1(20)

Narkunienė J, Ulbinaitè, A. 2018. Comparative analysis of company performance evaluation methods. Entrepreneurship and Sustainabi- 
lity Issues 6(1): 125-138. https://doi.org/10.9770/jesi.2018.6.1(10)

Nguyen, D., N., Imamura, F., Iuchi, K. 2017. Public-private collaboration for disaster risk management: A case study of hotels in Matsushima, Japan. Tourism Management 61:129-140. https://doi.org/10.1016/j.tourman.2017.02.003

Niño-Amézquita, J.; Dubrovsky, V.; Jankurová, A. 2017. Innovations and competitiveness in regional development: a comparison of Latin America, Europe, and China. Czech Journal of Social Sciences, Business and Economics 6(1):28-36. https://doi.org/10.24984/ cjssbe.2017.6.1.4

Padhi, S. S.; Theogrosse Ruyken, P.; Das, D. 2015. Strategic revenue management under uncertainty: a case study on real estate projects in India. Journal of Multi Criteria Decision Analysis 22(3-4):213-229. https://doi.org/10.1002/mcda.1537

Radovic, D.; Strielkowski, W.; Wang, J.; Cepel. M.; Rausser, G. 2017. Economic analysis of sustainable tourism: a case study of Nottingham. Transformations in Business \& Economics 16(2B):703-714.

Rais, R. 2010. Úvod do řízení podniku v krizi [Introduction to the crisis management of a company]. Brno: Rašínova vysoká škola.

Ravenswood, K. 2011. Eisenhardt's impact on theory in case study research. Journal of Business Research 64(7):680-686. https://doi. org/10.1016/j.jbusres.2010.08.014

Russel-Jones, N. 2016. The Management Change: Pocket Book, $4^{\text {th }}$ edn., Business and Economics, New York.

Smejkal, V.; Rais, K. 2009. Řízení rizik ve firmách a jiných organizacích [Managing risks in firms and other organizations]. $3^{\text {rd }}$ edn., Praha: Grada.

Strielkowski, W.; Abrhám, J.; Herget, J. 2014. Success factors of growth and development for small and medium enterprises in tourism sector. Journal of Applied Economic Sciences 9(27):101-109.

Tvaronavičienė, M. 2018. Toward efficient policy making: forecasts of vulnerability to external global threats, Journal of Security and Sustainability Issues 7(3): 591-600. https://doi.org/10.9770/jssi.2018.7.3(18)

Vasylchak, S.; Halachenko, A. 2016. Theoretical basis for the development of resort services: regional aspect. International Economics Letters 5(2):54-62. https://doi.org/10.24984/iel.2016.5.2.3

Veselovská, S.; Korauš, A.; Polák, J. Money Laundering and Legalization of Proceeds of Criminal Activity, Second International Scientific Conference on Economics and Management - EMAN 2018, March 22, 2018, Ljubljana, Slovenia, Printed by: All in One Print Center, Belgrade, 2018, ISBN 978-86-80194-11-0, DOI: https://doi.org/10.31410/EMAN.2018

Volchik V, Klimenko 1, Posukhova O (2018) Socio-economic sustainable development and the precariat: a case study of three Russian cities. Enterpreneurship and Sustainability Issues 6(1): 411-428. https://doi.org/10.9770/jesi.2018.6.1(25)

Waikar, V.; Hegde, D.; Borde, N. 2016. Hotel's grid group structure and risk management practices. Tourism Review 71(3):192-204. https://doi.org/10.1108/TR-03-2016-0006

Zemguliene J, Valukonis. M. 2018. Structured literature review on business process performance analysis and evaluation. Entrepreneurship and Sustainability Issues 6(1): 226-252. https://doi.org/10.9770/jesi.2018.6.1(15)

Zuzák, R.; Königová, M. 2009. Krizové ř́zení podniku [Crises management of a company]. Praha: Grada Publishing. 